\title{
DIFFERENCES OF EFFECTIVENESS OF COOPERATIVE LEARNING LEARNING MODEL TYPE TEAMS GAMES TOURNAMENT (TGT) AND GROUP WORKING ON LEARNING RESULT AT ELEMNTARY SCHOOL
}

\author{
Heru Mudiyanto \\ PGMI IAIN Syekh Nurjati Cirebon \\ herumudiyanto@gmail.com
}

\begin{abstract}
This research is based on the general problem, that is how the effectiveness of the implementation of cooperative learning model type TGT and group learning method to improve learning outcomes in social studies subjects in grade VI of elementary school in the aspect of knowledge, understanding and application, and to see if there are differences Significance between cooperative learning method of TGT type with ordinary group learning method. The research method used is quasi experiment with sample of student of class VI of SD Negeri Selaawi I and II. Research instrument in the form of learning result test. The hypothesis was tested using Mann-Whitney $U$ test with a significance level of 0.05. The result of this research is TGT model can improve learning outcomes and more effective than the usual group work model. Keywords: learning model, cooperative learning type TGT, group work.
\end{abstract}

\section{INTRODUCTION}

Along with the development of science and technology, life of society, nation, and state also experienced the development and change. This demands the need for improvement of the national education system including the refinement of the curriculum. The curriculum is an absolute requirement for formal education. Hilda Taba (in Waspodo: 2002) defines the curriculum as "a plan of learning", something that is planned to be learned by students. The curriculum is an integral part of education or learning. In the whole process at school, learning is the most important activity. This means that the successful achievement of educational goals depends largely on how the learning process can take place effectively. The curriculum applicable to schools today should be able to change the learning system from teacher-oriented to student-oriented learning. Students in the learning process are still introduced with a concept that success refers more to competition than cooperation.

The competition's arena has indirectly educated and galvanized students, always trying to find a way out to win the competition by justifying all sorts of ways. The principle is carried over after completion or graduation even brought to work, so the workplace is a continuation of the competition arena created by the school. Yet to be successful, the organization must be able to create a climate of cooperation. In a sense, cooperation and harmonious relationship between members, it is one of the requirements that must be met by the organization to achieve its goals. The learning process that emphasizes the importance of 
co-operation rather than competition and interdependence rather than independence is emphasized by Flynn and Graham (in Asrori, 2001: 1) they assert that:

"If a competition is developed, then there is a tendency to lead students to the mind and feelings of reluctance to attack others. Meanwhile, the development of cooperation and interdependence can actually develop the ability to face the challenges, leadership, and management that are needed if they have entered the workforce."

It has been described above that the learning affects the achievement of educational goals. To achieve the educational objectives, required learning components namely objectives, materials, media, evaluation tools, and that is not less important is the method of learning. In line with what is said Nurhadi, one of the alternative learning methods that can be implemented so that students are actively cooperative learning method. This method is commonly called the method of cooperation. The nature of learning cooperative learning is not the same as group learning. This model is constituted by the philosophy of homo hominisocius, which emphasizes, man is a social creature. This means, cooperation is a very important need for human survival. This learning model is very suitable to be applied in our country. Because, our nation is a nation that is very proud of the nature of mutual cooperation in social life. In group work the teacher usually divides the group and then assigns group assignments without specific design that can make each student active. As a result, students are active, but some are passive, or even play or chat. Meanwhile, in cooperative learning, every student is required to work in groups through certain designs that have been prepared by the teacher so that students can work actively.

Lie explained in his book Coopeartive Learning (Lie, 2005: 31), there are 5 elements of learning cooperative learning model, including:

1. Positive interdependence between group members.

2. There are individual responsibilities. That is, every member of the group must perform its duties well for the success of group work.

3. The presence of face to face, each group should be given the opportunity to meet face to face and discuss.

4. There should be communication between members. In this case students must be equipped with communication techniques.

5. Evaluation of group process, which is scheduled and implemented by the teacher.

Ironically cooperative learning learning model has not been widely applied in Indonesia, although Indonesian people are very proud of the nature of mutual cooperation in social life. There are several reasons why teachers are reluctant to use cooperative learning 
learning models, such as the fear that there will be chaos in the classroom and students not learning if they are placed in groups, many students are not happy to work with others, diligent students feel they have to work beyond The other students in their group, while the less able students feel inferior to be placed in a group with the smarter students. Teams Games Tournament (TGT) is one type of cooperative learning. TGT was developed by Slavin and De vries in 1990. The emphasis of TGT lies in the cooperation among group members in contributing scores to the advancement of group values in addition to individual values.

According to Rustaman and Widodo (Sofiraeni, 2001: 2) the teaching of social studies is still a difficult task for elementary school teachers, due to the lack of skilled teachers in using teaching methods, and the diversity of IPS teacher conceptions of learning and teaching. Therefore, this research is done in Elementary School (SD) on cooperative learning type TGT on IPS subjects. From the observations of Alfiati and Nurjhani (Sofiraeni, 2001:3) conducted in three elementary schools in Bandung and in the three elementary schools in Tasikmalaya district, it is obtained that among other things science teaching has not optimally considered the characteristics of IPA and the characteristics of elementary school children as appropriate. This can be seen from some of the more dominant teaching of science teaching using lecture and question and answer methods. IPA lesson targeted by elementary school teachers solely for students to be skilled at doing exam test questions. This type of TGT is suitable for elementary school because it contains elements of the game, as the Shah (1997: 51) children aged between 7-12 years old are in the late childhood stage with the following characteristics: 1) having the urge to get out of the house and enter Peer group; 2) the physical circumstances that encourage the child to enter the world of games and jobs that require physical skills; 3) have a mental impulse to enter the world of concepts, logic, symbols, and extensive communication. IPS learning in elementary school is successful if the knowledge, attitudes, and skills possessed by students as a result of teaching and learning process is useful for their daily life, as well as the provision to continue their education to secondary education level.

In accordance with the background of the problems that have been raised, the general problem that will be studied is "How effective implementation of cooperative learning model type TGT and group learning methods to improve learning outcomes in social studies subjects in grade VI SD".

This study aims to examine the effectiveness of cooperative learning model type Teams Games Tournament (TGT) and group learning methods, improve students' learning motivation in social studies subjects, and improve student learning outcomes in social studies 
subjects. The results of this study are expected to be useful for the parties concerned, including:

1. For Researchers; This research is used as a vehicle for deepening knowledge and increasing insight of researcher about cooperative learning model type TGT and group learning method.

2. For the Department of Education Curriculum and Technology; As a contribution to the development of science in the Curriculum and Technology Education Department, especially about cooperative learning model type TGT and group learning methods.

3. For Master; Can be used as information in developing the learning model used to improve the quality of teaching and learning process, especially cooperative learning model type TGT and group learning methods.

4. For Students; Provide learning experience to improve learning outcomes especially subjects IPS.

\section{METHODS}

The approach used in this research is experiment with design "Control Group Pre-test and Post-test design". Research subjects were placed into two classes of experimental groups given treatment by cooperative learning learning type TGT, and the control group who did the learning process with the method of group work on social studies subjects. In this case the subjects were placed in the experimental and control groups, both of which were pre-test and post test.

Researcher set two classes as sample, that is student of class VI SDN Selaawi I and II. In accordance with the problems to be solved, then in this study instrument used is a test instrument. The test to be used is objective test or multiple choice with four alternative answers which items are taken from the subjects of Social Science Class VI. The number of questions used is the number of questions that really have the right and in accordance with the purpose of the instrument grille. Data processing in this study using the help of computer software SPSS 11.0.

\section{RESULTS AND DISCUSSION}

\section{Learning model}

The term of the learning model is very close to understanding the learning strategy. According Soedjadi (Widdiharto, 2004: 3), learning strategy is a tactic of learning activities that aim to change a state of learning is now a learning state is expected. To change that 
situation can be pursued by various learning approaches. Furthermore Soedjadi mentioned that in one approach can be done more than one method and in one method can be used more than one technique. Simply can be traced as a series:

\section{Technique $\rightarrow$ Approach $\rightarrow$ Method $\rightarrow$ Strategy}

Learning model proposed by Lie (2005: 23) include:

Model Competition

In this model students learn in a competitive situation. Not infrequently also, teachers use rewards and rewards as a means to motivate students in winning competition with fellow students. The purpose of evaluation in this model is to place students in the order from the best to the ugliest. This model can create an atmosphere of hostility in the classroom. One of the philosophies underlying the spirit of competition is Darwin's Theory of Evolution, which says that who is strong is who wins and endures in life.

A. Individual Model

In this model, each student learns at a pace that suits their own abilities. In individual teaching, the scoring pattern is that the teacher sets the standard for each student. The assumption of individual teaching is that each student can learn on their own without or with little help from the teacher, and each student is unique with all his habits, abilities, interests and talents that are very different from the others.

B. Cooperative Learning Model

The philosophy underlying this learning model is Homo HominiSocius, that man is a social being. Cooperative learning model is not the same as simply learning in groups. Cooperative Learning is more an effort to empower peers, increase interaction among students, and mutually beneficial relationships among them.

Effective learning means combining different approaches or methods in learning that are prepared for learners according to their needs. The expected method can make the class more lively, challenging, and fun one of them is cooperative learning method.

\section{Cooperative Learning}

Cooperative learning is a learning model that is student center, meaning that in the learning process students are required to be active. The objectives of this cooperative learning include:

1. Give each student a chance to develop problems rationally.

2. Develop social attitudes and spirit gotong royong in life.

3. Mendinamiskan group in learning, so that each group feel themselves as part of the group responsible. 
4. Develop leadership skills in each group in solving group problems.

Linda lundgren (Falah, 2004: 9) provides some research results that show the benefits of cooperative learning for students with low results include:

1. Increases time out on tasks.

2. The sense of self-esteem is higher.

3. Improving attitudes toward science and everything.

4. Fixed attendance.

5. The dropout rate is lower.

6. Acceptance of individual differences becomes greater.

7. Disruptive behavior becomes smaller.

8. Interpersonal conflict is reduced.

9. Apathy decreases.

10. A deeper understanding.

11. Greater motivation.

12. Learning outcomes are higher.

13. Retention is longer.

14. Improving kindness, sensitivity and tolerance.

\section{Teams Games Tournament}

Teams Games Tournament (TGT) is one type of cooperative learning. TGT was developed by Slavin and De vries in 1990. The emphasis of TGT lies in the cooperation among group members in contributing scores to the advancement of group values in addition to individual values. TGT contains an element of competition learning model because in TGT there is an academic tournament that is identical with the competition. Competition in TGT that stands out is not an individual competition, but a group competition. That's what drives each group member to have a high sense of responsibility for the group's progress. Another characteristic of the TGT is the presence of games-containing competitions.

\section{TGT Steps}

There are several steps that must be done if will implement cooperative learning type TGT namely:

1. Class presentation

The presentation in the class only concerns the subject matter and the explanation of the instructional technique to be used. The preparation of the subject matter is made in such a way that it can be presented in: class presentations, group learning, and academic tournaments. These activities are packaged in a learning device consisting of a learning unit 
program, a learning plan, learning materials and student worksheets (which students will learn in group learning), tournament equipment (which will be used in an academic tournament) and a test of learning outcomes that will Tested after the learning is complete.

2. Study groups

The learning group is the formation of groups consisting of 4-6 students with varying abilities, group members representing the existing strata in terms of academic ability, gender and race. The main activity at this stage is the students studying the teaching materials in accordance with the material being studied and working on the LKS in groups. During the study group of students is always in the group, the task of group members is to learn or master the material being studied.

\section{Academic tournament}

In TGT type cooperative learning, academic tournaments aim to test the knowledge that each student has achieved. The tournament matter is composed in the form of questions relating to the material being studied. Each member in one group goes to a different tournament table, each tournament table is performed by three or four students who have equal academic ability. The equipment used for the tournament is "question cards" and "answer cards". The first student takes one card and reads the question aloud so that the other students can listen and then answer it, if they can not answer, the student can declare through and be thrown to the student who gets the second turn. But if the first student can answer and the second student has a "different" answer from the first student, the second student can "challenge" the first student. If the second student is not challenging then a challenging opportunity can be given to the student who gets the next turn (third student) and so on. The student who answers the question correctly, then can save the question card as evidence that the student can answer the given problem correctly. An answer card is read by the student who got the last turn. At the end of the tournament a card count has been collected for the students to determine the student's score in the tournament.

Any student who has equivalent academic ability and represents different groups competes to get maximum score and strive to contribute to his group. To illustrate the relationship between a heterogeneous group of members with a tournament table whose members are homogeneous can be seen in the following figure. 
Group A Group B

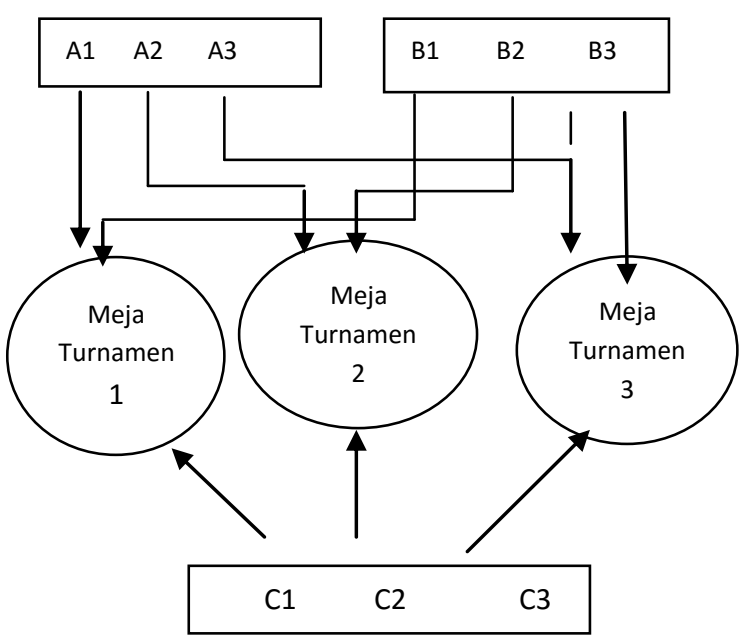

\begin{tabular}{cc}
\hline Value & Criteria \\
\hline Value $>50$ & Super Team \\
$45<$ Value $<50$ & Great Team \\
$40<$ Value $<45$ & Good Team
\end{tabular}

\section{Student Placement On Tournament Table}

After the tournament is over then the score counts, the teacher reorganizes the student's position for the next tournament. Students who get the highest score from each tournament table are positioned one level to the tournament table which has a higher level than the original table, while the students who get the lowest score will shift to the table of tournaments that have lower levels than the original table. Students who score the highest on a table with the highest level, the position can not be shifted again. Likewise students who score the lowest on the table low-level tournaments, can not be shifted again.

4. Group awards, at each end of the tournament a score count is performed, to determine which group has the highest score. Group award criteria according to Slavin (Melani, 2005: 26):

5. Bumping (shifting), ie shifting positions for each student on the table of the tournament, performed every completed academic tournament, to set the position of students in the next competition. The shift in position is based on the score obtained by the students.

\section{GROUP METHODS}

Robert L. Cilstrap and William R. Martin (Roestiyah, 1988: 15) provide the notion of group work as "The activity of a small group of students, organized for learning purposes". To use this method the teacher must be absolutely sure that the topic being discussed is suitable for use in group work.

32 | Differences of Effectiveness of Cooperative Learning Learning Model Type Teams Games Tournament (TGT) and Group Working on Learning Result at Elemntary School 
The method of group work is used in teaching and learning process with the aim of:

1. Fostering willingness and cooperation skills among students.

2. Increase the students' socio-emotional and intellectual involvement in the teaching and learning process.

3. Increased attention to the process and outcomes of the learning process in a balanced way.

The advantages of working group method are:

1. Provide an opportunity for students to use questioning skills and discuss issues.

2. Provide opportunities for students to more intensively conduct an investigation on a case.

3. Develop leadership talents and teach discussion skills.

4. Allows teachers to pay more attention to students as individuals and their learning needs.

5. Students become more active in the discussion.

6. Giving opportunities for students to develop a sense of appreciation and respect for their friends.

The learning steps of the group work method are:

1. Explain the task to the student.

2. Explain the purpose of the group's work.

3. Divide the class into groups.

4. Each group appoints a recorder who will report on the progress and results of the group's work.

5. Teacher walks around during group work, if necessary give advice.

6. Reporting of group work.

7. Teachers help to conclude progress and accept group results.

\section{Learning Outcomes}

Ebel (Arikunto, 2002: 115) argues that: "If educational outcomes are important but can not be measured then those goals must be changed. If the objectives have been formulated operationally then the results will be measurable. A sign that a person has achieved his goal, will be seen in his behavior change." The result of the learning process is the change of individual behavior. Individuals will acquire new, settled, functional, and conscious behaviors. Gagne (Surya, 2003: 25) suggests that learning outcomes are human skills that include: (1) verbal information, (2) intellectual skills that include: discrimination, concrete concepts, abstract concepts, rules, higher rules, (3) ) Cognitive strategy, (4) attitude, and (5) motor skills. Benjamin Bloom (Surya, 2003: 25) mentions there are three areas of behavior as a result of learning are: (1) Cognitive; (2) Affective; And (3) Psychomotor. 
TGT learning requires students to mutually depend on their fellow group members. That way students can increase knowledge about the subject matter. This learning model creates a situation where individual student success is spurred by all members of the group so that if one of the group members can not master the material especially on the knowledge aspect or can not answer the question in the academic tournament quiz, it can be detrimental to the group score. In contrast to the method of learning group work, on the method there is no positive dependence among group members. Students who diligently will do group work well, while other students just rely on friend's intelligence.

TGT learning requires students to have individual responsibilities, each group member must carry out their own responsibilities while performing an academic tournament, so every student is required to master the material. This learning creates a situation where the only way to learn so that group members can achieve their personal goals, group members must help their group mates by doing anything that can help the group to succeed and perhaps more important is to encourage the group's friends to make the effort The maximum.

In TGT learning group members consist of heterogeneous students, so during group discussions if one group member does not understand the material or task assigned, it can ask that question to his or her friends in a smarter group. So with the group discussion, it is clear here that the students can better understand the subject matter clearly. In contrast to the method of group work, there is no group discussion on the method, so there is no opportunity for students to better understand the subject matter. In TGT learning, students are given tasks by teachers to work on and discuss with friends in one group. The task given by the teacher consists of issues that can improve the mastery of the material, especially aspects of application. At the time of group discussion is an opportunity for students to master the material, so that during the academic tournament, students can answer all the questions posed. Students who use the TGT method will be more motivated in mastering the material whether it is knowledge, understanding, or application aspects.

From the three above discussion it can be seen that by using TGT learning model can improve learning motivation for students. That way students can better master the material either aspects of knowledge, understanding, and application. From the results of data processing, can be seen the results that show the differences in student learning outcomes using learning methods cooperative learning TGT type and students using group learning methods on the subjects of Social Studies class VI in elementary school. 


\section{CONCLUSION}

In TGT learning, each group should be given the opportunity to meet face to face and discuss. The thought of some heads will be richer than the thought of a single head. The core of the face-to-face aspect is to appreciate the differences, take advantage of the advantages, and fill in their respective deficiencies. Similarly, the aspect of communication among members, the success of the group also depends on the willingness of its members to listen to each other and their ability to express their opinions. While the group process evaluation aspect, the advantage that can be taken from that aspect is that each member of the group will be awarded by the teacher in accordance with the scores of the group. So each group will compete to collect the most score. This means that cooperative learning learning can increase students' motivation to learn.

All of which becomes clearer with the results of the research obtained, where as students follow the stages of TGT learning, allowing students to be more active, and motivated to remember the subject matter. From these advantages can be seen the difference between TGT and group work. In the group work method there is no positive dependence, individual responsibility to each member of the group, and no appreciation given by the teacher. After all the group members do their work, the teacher only assigns value to the task. So it is clear that cooperative learning type TGT is more effective than the method of group work.

\section{ACKNOWLEDGMENTS}

The researchers would like to thank all parties who have supported this research both in terms of morale and material especially in IAIN Sheikh Nurjati Cirebon and SD Negeri Selaawi I and II.

\section{REFERENCES}

Arikunto, S. (2002).Prosedur Penelitian, Suatu Pendekatan Praktek. Jakarta: PT Rineka Cipta

Asrori, M. (2001).Colaborative Team Work Learning: Suatu Model Pembelajaran Untuk Mengembangkan Kemampuan Mahasiswa Bekerja Secara Kolaboratif Dalam Team.Tersedia. http//www.depdiknas.go.id. [17 Mei 2006]

Falah, Y. (2004). Model-Model Dalam Pengajaran Untuk Membuat Pelajar Belajar Mandiri. Tersedia: http://www.geocities.com/guruvalah/artikel_pendidikan7.html. September 2006].

Lie, A. (2005). Cooperative learning: Mempraktikkan Cooperative learning di Ruang-Ruang Kelas. Jakarta: Grasindo 
Melani, E. (2005). Kemampuan Pemecahan Masalah Matematika Siswa SMKN Teknik Melalui Model Pembelajaran Kooperatif Tipe TGT. Skripsi (Tidak dipublikasikan). Bandung: UPI

Surya, M. (2003).Psikologi Pembelajaran Dan Pengajaran. Bandung: Yayasan Bhakti Winaya

Sofiraeni, R. (2001). Pengaruh Model Pembelajaran IPA Tematik, Interaktif, dan CLIS Terhadap Peningkatan Penguasaan Konsep Kemampuan Berpikir Rasional, Dan Keterampilan Proses IPS Siswa SD Kelas III. Tesis (Tidak dipublikasikan).Bandung:UPI

Syah, M. (1997). Psikologi Pendidikan. Bandung:Rosdakarya

Waspodo, M. (2002).Peranan Pamong Belajar Dalam Implementasi Kurikulum. Tersedia: http://www.depdiknas.go.id/Jurnal/35/editorial35.htm. [25 Juni 2006]

Widdiharto, R. (2004). Model-Model Pembelajaran Matematika SMP. Yogya: Pusat Pengembangan Penataran Guru. 